Edu Sciences J. Vol. 1, No. 1. March 2020, 1-7

\title{
APPLICATION OF PICTURE AND PICTURE MODELS IN IMPROVING WRITING SKILLS DESCRIPTION CLASS IV STUDENT SUB THEMES THE WORK OF MY PARENTS MI MODERN MUTIARA IMAN KECAMATAN NGUNUT DISTRICT TULUNGAGUNG
}

\author{
Novialita Angga Wiratama* \\ PGRI Ronggolawe University \\ *email : novialita3@gmail.com
}

\begin{abstract}
Based on observations during the learning process in Class IV Madrasah Ibtidaiyah (MI) Modern Mutiara Iman students in writing activities, before writing a description of student activities listening to the teacher's explanation about writing a description through writing essays. Then, reading the text in the book, listing and interpreting difficult words with the group after that students with the group write a description essay then exchange the results of work on other groups. Individual students are given homework assigning descriptions with free themes. From the results of student writing there are some errors. From the results of interviews with students obtained data that students have difficulty in pouring ideas into writing. This can be seen in the unorganized writing ideas that will be developed, the suitability of cohesion and low coherence. Students immediately write what is in their minds without making a framework first. Students are less able to develop sentences into coherent paragraphs. There are many errors in the use of punctuation and spelling. This study aims to improve (1) the application of picture and picture models to improve description writing skills in Class IV students at MI Modern Mutiara Iman (2) increase learning outcomes of writing description skills in Class IV students at MI Modern Mutiara Iman. The subjects of this study were Class IV MI Modern Mutiara Iman students in the 2019/2020 school year with a total of 34 students. This type of research is a classroom action research (CAR) with three cycles, including four stages, namely: 1) planning, 2) implementing actions, 3) observations, and 4) reflection. Data collection techniques used in this study include: interviews, observations, tests, questionnaires, documentation, field notes. The results of the research during the process of writing descriptions in each cycle obtained data from 34 students in the first cycle as many as 14 students passed grade the specified scor 70 . In the second cycle 26 students passed grade and 31 students passed grade in the third cycle. There are 2 students do not passing grade because they have difficulty writing essay writing so that they need more intensive study guidance compared to their peers.
\end{abstract}

Keywords: Elementary Indonesian Language Learning, Picture and Picture Models, Writing Essay Descriptions

\section{Introduction}

Humans can not be separated from learning both formal and informal learning. According to Komalasari (2013: 3), learning is a system or process of learning the learner that has been planned, implemented and evaluated systematically so that learners can achieve learning objectives effectively and efficiently. To achieve learning objectives, we can use strategies, methods or model. Thematic learning is an alternative learning model that can support the process of humanization in the process of primary school education. Kadir (2014, p.1). Thematic learning is a learning program that departs from a particular theme / topic and then is elaborated from various aspects or viewed from several subject perspectives that can be taught in schools. Thematic approach is expected that students are able to independently improve and use their knowledge to examine the values of character and noble character so that it is manifested in daily behavior.

Received September $9^{\text {th }} 2019$, Revision January $15^{\text {th }} 2020$, Accepted for publication February $18^{\text {th }} 2020$.

Copyright (C) 2020 Published by FKIP - Unpatti, ISSN 2721-3110 
The essence of learning Indonesian is learning communication properly and correctly both verbally and in writing. Language has a central role in the intellectual, social and emotional development of students and is a supporter of success in learning all fields of study. Writing is one of the language skills that must be possessed by people who use language or who learn a language. Writing is a language skill in communicating every human being in everyday life, not only by talking people can convey messages to others. Writing is a communication activity in the form of delivering messages (information) in writing to other parties using written language as a tool or medium (Dalman, 2014: 3). One type of writing or essay in elementary school is writing a description essay. Description is "essay that presents a series of events in the order of events (chronological) with the intention of giving meaning to an event or series of events and so that the readercan learn lessons from that story "(Suparno, 2010: 4.54). Essay description is a form of writing that is related to the efforts of the writers to provide details of the object being discussed. In the description, the writer moves his impressions, transfers his observations and feelings to the reader

The results of observations in Class IV MI Modern Mutiara Iman students, that learning to write descriptions of Class IV students in MI Modern Mutiara Iman is still not optimal. Most students are able to write well, but students still find it difficult to pour out their ideas on an ongoing basis using good and correct Indonesian. Students write descriptions not sequentially from sentence one to the next sentence so that the writing storyline is difficult for teachers and other students to understand who act as readers. In addition, students also still find it difficult to choose the words used in writing the description and start writing the description. This results in the value of writing skills description of Class IV students in MI Modern Mutiara Iman is still relatively low.

Before writing a description of student activities before writing a description of student activities listening to the teacher's explanation about writing descriptions through writing essays. Then, reading the text in the book, listing and interpreting difficult words with the group after that students with the group write a description essay then exchange the results of work on other groups. Individual students are given homework assigning descriptions with free themes. From the results of student writing there are some errors. From the results of interviews with students obtained data that students have difficulty in pouring ideas into writing. This can be seen in the unorganized writing ideas that will be developed, the suitability of cohesion and low coherence. Students immediately write what is in their minds without making a framework first. Students are less able to develop sentences into coherent paragraphs. There are many errors in the use of punctuation and spelling. In overcoming this, there are several learning models that can be applied, one of which is the picture and picture model.

The model is defined as an object or concept that is used to represent something. According to Arends (Trianto, 2010: 17) argues that the learning model is "a plan or a pattern that is used as a guide in planning learning in class". One of the skills of teachers who play an important role in learning is the skill to choose learning models. The more precise the learning model used by the teacher in teaching, it is hoped that the more effective the achievement of learning objectives. Therefore, the function of the learning model cannot be ignored because the learning model also determines the success or failure of learning. Suprihartiningrum (2013: 143), that the quality and success of learning is strongly influenced by the ability and determination of teachers in choosing and using learning models.

There are various kinds of learning models that are suitable to be applied in learning to write descriptive essays, one of which is the picture and picture model. Picture and picture is "a learning model that uses pictures and is paired or sorted into a logical sequence" (Suparno: 2011). Model picture and picture suitable for writing a description essay. Istarani (2011: 31) The step in applying the picture and picture model begins with

Received September $9^{\text {th }} 2019$, Revision January $15^{\text {th }} 2020$, Accepted for publication February $18^{\text {th }} 2020$.

Copyright (C) 2020 Published by FKIP - Unpatti, ISSN 2721-3110 
the teacher delivering the learning objectives, providing introductory material before the Learning activities.

In using the learning model must be adapted to the concept that is more suitable and can be integrated with other models or learning methods to improve student learning outcomes. Departing from the description above, it is necessary to solve the learning problem with the title "the application of picture and picture models to Improve the Skills of Writing Descriptions in Class IV MI Modern Mutiara Iman Students".

\section{Research Methods}

This research is a type of classroom action research with a descriptive qualitative approach. Qualitative approach is a research procedure that produces descriptive data in the form of written or oral words from people and behavior that can be observed by Bogdan (in Moleong, 2007: 4). This type of research is Classroom Action Research (CAR). CAR is an examination of learning activities carried out by teachers to solve learning problems in class. CAR is how a group of teachers can organize the conditions of their learning practices, and learn from their own experiences (Wiriaatmadja, 2007: 66).

The CAR design used in this study uses the Kemmis and M.C Taggart models (in Akbar, 2010: 28) including four steps, namely (1) formulating the problem and planning the action; (2) carrying out actions according to plan; (3) observing or monitoring the implementation of actions; (4) reflecting the results of observations as a basis for planning further actions. This research was conducted at MI Mutiara Iman in Class IV students. The researcher acts as the executor of the action assisted by the Class IV teacher as an observer. The subjects in this study were all Class IV students in the 2019/2020 school year totaling 34 students.

Data collection is done by observation, test, documentation, and field notes techniques. Analysis of the data obtained must be tested for its validity by using triangulation techniques. The analysis begins by collecting data through observation, tests, documentation, and field notes. The data that has been collected is then selected according to the purpose of the study. Then the data is written coherently based on each data collection instrument used. The next step is to integrate data obtained from several data collection instruments. The results of the data integration are carried out in order to obtain valid and reliable data, which then the data are analyzed and concluded.

\section{Results And Discussion}

\section{a. Action Observation Results}

\section{Data Description on the Action Observation}

The first observation activities are introduction observations, the way to observe how to teach teachers in class and conduct unstructured questions and answers. Observations were made on writing essay learning activities being carried out in Class IV MI Modern Mutiara Iman. Learning is not based on thematic. In addition, learning tends to use the traditional approach with the following characteristics: (1) learning tends to use lecture and assignment methods, (2) students learn individually, (3) students accept learning students take notes, hear and carry out tasks that have been given the teacher and students are only given a few opportunities to give their ideas.

Based on observations obtained data as follows: (1) learning using the lecture method, (2) students do not pay attention to learning, (3) students who sit on the back bench do not actively participate in learning (4) some students who lack confidence or inferior, (5) ) media, models and learning methods used have not stimulated students to 
be able to write a description, (6) students spawn learning motivation. From the observations obtained information that before writing a description of activities students read the text in student books, record and interpret difficult words with the group. Then exchange work results with other groups. Individual students were given home assignments to write essays of descriptions with unspecified themes. From the results of student writing there are some errors. Among them, difficulties in pouring ideas into writing, this is seen in writing that is not arranged ideas that will be developed. Students immediately write what is in their minds without making a framework first so that the flow in writing is not coherent. Students are less able to develop sentences into coherent paragraphs. There are many errors in the use of punctuation and spelling. This is evident in the scores obtained by students, namely many students who scored below the specified KKM of 65 . Of the 34 students there were 12 students who scored above the KKM while 22 students gota value below the KKM. In addition, it can also be seen that the average value of students still reaches 63 . Therefore, the learning must be improved.

\section{B. Troubleshooting Results}

\section{Cycle Action I}

\section{a. Action Planning}

The action plans compiled include: (a) the making of the Learning Implementation Plan (RPP) using the picture and picture model, (b) preparing the learning media, (c) preparing the Group Worksheet (LKK), (c) preparing the final test questions, (d ) making an assessment of the process, attitudes and learning outcomes.

\section{b. Implementation of Actions.}

The action is described as follows: (a) at the beginning of learning the teacher says greetings, guides prayers and holds apperception to explore students' initial knowledge, (b) the teacher informs the material and learning objectives to be achieved, (c) the teacher divides students into several groups, (d) the teacher divides the group worksheets and media image series (pictures used by work profiles around students), (e) students are given the opportunity to ask questions, (f) students are guided by teachers in completing worksheets, (g) representatives of each group deliver the results of their work and other groups respond, (h) students with the teacher discuss the results of student work, (i) students are given the opportunity to ask questions about material that is not yet understood, (j) students get a final test of learning and do it individually, (k) students with the teacher discuss the results of the final learning test. Assessment of the process, attitudes and results during learning are described as follows the activities of students in the learning process are different. By using the picture and picture model, the value of the student process looks pretty good. This is evident in the scores obtained by students, namely many students who scored above the specified KKM of 70 . Of the 34 students there were 14 students who scored above the KKM while 20 students got grades below the KKM.

\section{c. Observation}

This observation is carried out during the learning process. The observation was carried out by an observer, a Class IV teacher at MI Modern Mutiara Iman. This observation was carried out to assess teacher activity in learning using the picture and picture model. The attitude of students in the learning process varies. There are 3 attitudes observed in the learning process, namely cooperation, courage and responsibility. By using the picture and picture model, the students' attitude values look good enough. Students can work together with all group members even though there are still students who appear to be

Received September $9^{\text {th }} 2019$, Revision January $15^{\text {th }} 2020$, Accepted for publication February $18^{\text {th }} 2020$.

Copyright (C) 2020 Published by FKIP - Unpatti, ISSN 2721-3110 
unable to blend in with the other group members. Student responsibility has begun to appear, this has been proven by the completion of the work done by each group member. The courage of students in delivering work results is still not visible. This is reflected when the teacher gives an offer to students to deliver the results of group work in front of the class but no one has advanced without the appointment by the teacher.

\section{d. Reflection}

The results of reflection on this first cycle of action include students needing practice to write descriptions individually given the professional media of their parents' work. Students need to be motivated in a continuous manner so that confidence arises so that they can convey the results of work in front of the class without being appointed by the teacher and convey it in straightforward language, clear and easily understood by other students.

\section{Cycle Action II}

\section{a. Action Planning}

The action plans compiled include: (a) preparation of the Learning Implementation Plan (RPP), (b) preparation of instructional media in the form of a professional drawing of each student's parents, (c) preparation of Worksheets (c) preparation of final test questions, (d) making assessment processes, attitudes and learning outcomes.

\section{b. Implementation of Actions.}

The implementation of the action is described as follows: (a) at the beginning of the learning the teacher says greetings, guides prayers and hold apperception to explore students' initial knowledge, (b) the teacher informs the material and learning objectives to be achieved, (c) the teacher divides students into several groups, (d) the teacher divides the worksheets and the professional drawing media to each student (e) students are given the opportunity to ask questions, (f) students are guided by the teacher in writing descriptive essays by observing pictures of the parental profession, (g) students make the main ideas that will be developed (h) students make draft essays of descriptions about the work of parents (i) students develop drafts writing a description essay (j) the teacher accompanies students during the process of writing a description essay (k) the results of student work exchanged with friends to be commented on and examine the accuracy of spelling writing in sentence (l) with the teacher discussing the results of writing description essays.

Assessment of the process, attitudes and results during the learning activities of students in the learning process varies. By using the picture and picture model, the students' process scores are seen to have improved compared to the cycle I action. This can be seen in the scores obtained by students, namely that many students have scores above the specified KKM of 70 . Of the 34 students there are 26 students who have grades in on KKM while 8 students got grades below KKM.

\section{c. Observation}

This observation is carried out during the learning process. The observation was carried out by an observer, a Class IV teacher at MI Modern Mutiara Iman. The attitude of students in the learning process varies. There are 3 attitudes assessed in the learning process, namely cooperation, courage and responsibility. By using the model picture and picture, the value of the attitude of students has seen an increase. This can be seen in students' enthusiasm in writing descriptive essays related to the profession of their parents. Students look very careful and thorough in writing description essays. Although

Received September $9^{\text {th }} 2019$, Revision January $15^{\text {th }} 2020$, Accepted for publication February $18^{\text {th }} 2020$. 
writing assignments are done independently, some students also help their friends who have difficulty when writing. The courage of students in presenting the results of work in front of the class has increased compared to the meeting cycle I. This is seen when the teacher allowing students to present the results of their work, students scrambling to read the written essay description in front of the class.

\section{d. Reflection}

The results of reflections on the second cycle of the fourth grade students of MI Mutiara Iman in writing this description essay have had a significant increase both in the learning outcomes of writing descriptions and in the attitudes of students during the learning process. To strengthen the ability of students to master writing a description essay needs to be done cycle III action.

\section{Cycle Action III}

\section{a. Action Planning}

The action plans compiled include: (a) the making of a Learning Implementation Plan (RPP) using a picture and picture model, (b) the preparation of learning media (students bring media in the form of professional photographs of students' aspirations), (c) preparation of student worksheets (c ) preparation of the final test questions, (d) making an assessment of the process, attitudes and learning outcomes.

\section{b. Implementation of Actions.}

The implementation of actions is a follow-up of the implementation of the second cycle of actions. The action is described as follows: (a) at the beginning of learning the teacher says greetings, guides prayers and holds apperception to explore students' initial knowledge, (b) the teacher informs the material and learning objectives to be achieved, (c) the teacher divides students into several groups, (d) the teacher divides the worksheets, (e) students are given the opportunity to ask questions, (f) students observe a photo of their ideals, (g) students independently make a written essay description with the theme of my goals (h) students exchange results work with friends (i) students correct each other's work (j) students present the results of written essays in front of the class description.

By using the picture and picture model, the value of the student's process is seen to improve in every action. In cycle III data obtained from 34 students there were 31 students who scored above the KKM while 3 students got grades below the KKM. The attitude of students in the learning process varies. In this third cycle students are already responsible for the taskeach student. Student collaboration is seen by the actions of students helping friends who are having difficulties. When presenting work results in front of the class, students look enthusiastic, not appointed by the teacher and orderly take turns with friends. Students dare to express comments written by a friend verbally in polite language and do not comment poorly on the work of other friends.

\section{c. Observation}

The results of observations of Class IV MI Modern Mutiara Iman students. The attitude of students in this third cycle students are already responsible for the tasks of each student. Student collaboration is seen by the actions of students helping friends who are having difficulties. When presenting work results in front of the class, students look enthusiastic, not appointed by the teacher and orderly take turns with friends. Students dare to express comments written by a friend verbally in polite language and do not comment poorly on the work of other friends.

Received September $9^{\text {th }} 2019$, Revision January $15^{\text {th }} 2020$, Accepted for publication February $18^{\text {th }} 2020$. 


\section{d. Reflection}

The results of reflection on the action cycle III using a picture and picture model in the activities of students writing a description essay showed significantly improved results, both in terms of writing ability and attitude in learning. There are 2 students in learning activities from the action cycle I to cycle III that have not shown significant development. The ability to write 2 students is still low but in the learning process, they follow well but when presenting learning outcomes in front of class 2 these students always choose the last turn and are not confident in delivering the results of the work.

\section{Conclusion}

The application of picture and picture models can improve the writing skills of description essays in Class IV MI Mutiara Iman students in Ngunut Sub-district, Tulungagung Regency. The improvement can be seen from the increased student learning outcomes. From the completeness of the activity of writing an essay description of the sub-theme of the work of parents in grade IV MI Mutiara Iman students. The results of the research during the process of writing descriptions in each cycle obtained data from 34 students in the first cycle as many as 14 students passed the specified KKM 70. In the second cycle 26 students passed the KKM and 31 students passed the KKM in the third cycle. From the observational data and field notes during the study the attitude assessment took place during the learning process which included collaboration, responsibility and confidence in conveying work results in each cycle experiencing a classical development. There are 2 students in the ability to write essays in incomplete description of KKM. During the learning process, they follow well but when presenting learning outcomes in front of class 2 these students always choose the last turn and are not confident in delivering the work. These 2 students need more intensive tutoring than their peers and need motivation from the teacher, friends and parents of students.

\section{REFERENCES}

Akbar, S. 2010. Penelitian Tindakan Kelas Filosofi, Metodologi, dan Implementasinya. Yogyakarta: Cipta Media Aksara.

Arifin, Zaenal. 2009. Evaluasi Pembelajaran. Bandung: PT. Remaja Rosdakarya.

Dalman. 2014. Keterampilan Menulis. Jakarta. Raja Grafindo Persada.

Huda, M. 2013. Model-model Pengajaran dan Pembelajaran. Yogyakarta: Pustaka Belajar.

Istarani.2011. Model pembelajaran picture and picture.

Kadir, Abd \& Hanun, Asrohah, (2014). Pembelajaran tematik. Jakarta: Prajagrafindo Persada

Moleong, J. L. 2007. Metodologi Penelitian Kualitatif. Bandung. Remaja Rosdakarya Yogyakarta: Cipta Media Aksara.

Suparno dan Yunus, Mohamad. 2010. Materi Pokok Keterampilan Dasar Menulis; 1-6. Jakarta: Universitas Terbuka.

Suparno, \& Mohammad Yunus. (2011). Keterampilan Dasar Menulis. Jakarta: Universitas Terbuka

Trianto, (2010). Mengembangkan model pembelajaran tematik.jakarta: Prestasi Pustaka

Wiriaatmadja, R. 2006. Metode Penelitian Tindakan Kelas. Bandung: Remaja Rosdakarya.

Received September $9^{\text {th }} 2019$, Revision January $15^{\text {th }} 2020$, Accepted for publication February $18^{\text {th }} 2020$.

Copyright (C) 2020 Published by FKIP - Unpatti, ISSN 2721-3110 